\title{
Imported Crimean-Congo hemorrhagic fever cases in Istanbul Kenan Midilli1 ${ }^{1}$, Ayşen Gargıl1 ${ }^{1}$, Onder Ergonul*2, Gönül Şengöz ${ }^{3}$, Recep Ozturk ${ }^{4}$, Mehmet Bakar ${ }^{3}$ and Frans Jongejan ${ }^{5,6}$
}

\begin{abstract}
Address: ${ }^{1}$ Istanbul University, Cerrahpaşa Medical Faculty, Microbiology and Clinical Microbiology Department, Istanbul, ${ }^{2}$ Marmara University, School of Medicine, Infectious Diseases and Clinical Microbiology Department, Istanbul, ${ }^{3}$ Ministry of Health of Turkey, Istanbul Unit, ${ }^{4}$ Istanbul University, Cerrahpaşa Medical Faculty, Infectious Diseases and Clinical Microbiology Department, Istanbul, ${ }^{5}$ Utrecht Centre for Tick-borne Diseases (UCTD), Department of Infectious Diseases and Immunology, Faculty of Veterinary Medicine, Utrecht University, the Netherlands and ${ }^{6}$ Department of Veterinary Tropical Diseases, Faculty of Veterinary Science, University of Pretoria, South Africa
\end{abstract}

Email: Kenan Midilli - kmidilli@istanbul.edu.tr; Ayşen Gargıll - agargili@yahoo.com; Onder Ergonul* - onderergonul@yahoo.com; Gönül Şengöz - drgonul@ hasekihastanesi.gov.tr; Recep Ozturk - ozturkrecep@superonline.com; Mehmet Bakar - mehmetbakar@yahoo.com; Frans Jongejan - F.Jongejan@vet.uu.nl

* Corresponding author

Published: 6 June 2007

BMC Infectious Diseases 2007, 7:54 doi:10.1/86/147/-2334-7-54
Received: 15 January 2007

Accepted: 6 June 2007

This article is available from: http://www.biomedcentral.com/I47/-2334/7/54

(c) 2007 Midilli et al; licensee BioMed Central Ltd.

This is an Open Access article distributed under the terms of the Creative Commons Attribution License (http://creativecommons.org/licenses/by/2.0), which permits unrestricted use, distribution, and reproduction in any medium, provided the original work is properly cited.

\begin{abstract}
We described a series of imported cases of Crimean-Congo Hemorrhagic Fever (CCHF) in Istanbul and investigated the genetic diversity of the virus. All the suspected cases of CCHF, who were applied to the health centers in Istanbul, were screened for CCHF virus (CCHFv) infection by using semi-nested Polymerase Chain Reaction (PCR) following RT-PCR. Simultaneous blood samples were also sent to the national reference laboratory in Ankara for serologic investigation. In 10 out of 91 patients, CCHFv was detected by PCR, and among 9 out of I0, anti-CCHFv IgM antibodies were also positive. Clinical features were characterized by fever, myalgia, and hemorrhage. The levels of liver enzymes, creatinine phosphokinase, and lactate dehydrogenase were elevated, and bleeding markers were prolonged. All the cases were treated with ribavirin. There was no fatal case. All the strains clustered within the same group as other Europe/Turkey isolates.
\end{abstract}

\section{Background}

Crimean-Congo hemorrhagic fever (CCHF) is a fatal viral infection described in about 30 countries over the world. It has the most extensive geographic range among the medically significant tick-borne viruses [1]. The occurrence of CCHF closely approximates the known world distribution of Hyalomma spp. ticks. The virus belongs to the genus Nairovirus in the Bunyaviridae family and causes severe diseases in humans, with a reported case fatality rate of 3-30\% [1]. CCHF outbreak in Turkey was reported in 2003 [2-4]. By the year 2006, 1103 CCHF confirmed patients were recorded at the Ministry of Health $(\mathrm{MOH})$ of Turkey [5]. The diagnoses of these cases were per- formed by detection of the virus by PCR or IgM and/or IgG positivity by ELISA. All these patients were hospitalized, 59 of them died, and the case fatality rate was calculated as $5.3 \%$. A great majority of the cases were seen in the eastern Anatolia. No local case was reported from Istanbul yet. However, cases were recently observed in other regions of the country, and the rate of the domestic travel and mobility is high in the country.

Humans become infected through the bites of ticks, by contact with a patient with CCHF during the acute phase of infection, or by contact with blood or tissues from viremic livestock [6]. In 1969, the antigenic structures of 
the viruses from various geographic regions were reported to be indistinguishable [7]. However, the development of nucleic acid sequence analysis revealed extensive genetic diversity. Furthermore, more data on the genetic sub-types of the viral strains could shed light on the transmission dynamics of the virus. In this study we describe the genetic variation and clinical characteristics of the CCHF cases observed in Istanbul, in the western part of the country.

\section{Methods}

\section{The Management of the cases}

Istanbul unit of the MOH established an ad hoc committee for the management of a potential CCHF infection in the city. The group defined the organizational flow for the management of the suspected cases. The suspected cases were defined as the cases with symptoms or signs of CCHF such as fever, myalgia, malaise, and bleeding, and also the history of travel to the endemic region or tick bite. The patients with acute febrile syndrome characterized by malaise, bleeding, leukopenia, and thrombocytopenia in the summer months of 2006 were admitted to the various hospitals of Istanbul (Figure 1).

The patients who had positive IgM and/or IgG and/or positive PCR results for CCHFV in blood were included to the study. The IgM and IgG positivity was detected by using ELISA [8]. Serology for Lyme disease, Salmonella, Leptospira, Rickettsiae, Brucella, and Coxiella infections were investigated. STATA 9.0 (USA) software package was used in the analysis.

\section{RNA extraction, PCR procedures and construction of phylogenetic tree}

Whole blood samples drawn into EDTA containing vacutainer tubes from these suspected cases were sent to Istanbul University Cerrahpaşa Medical Faculty, Microbiology

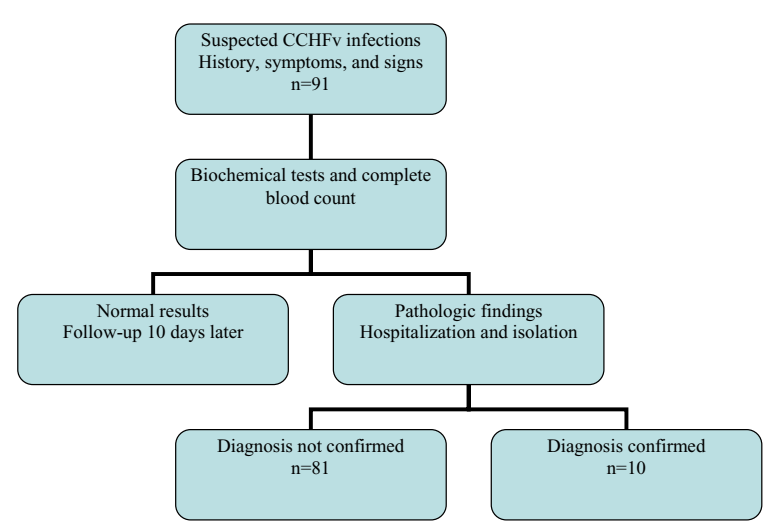

Figure I

The organization scheme for the suspected cases. and Clinical Microbiology Department as local reference laboratory. Upon receipt RNA was extracted from $200 \mu \mathrm{l}$ whole blood using a commercial RNA extraction kit (High Pure Viral Nucleic Acid Kit, Roche Diagnostics ${ }^{\circledast}$, Germany). The extracted RNA and remaining blood were aliquoted and stored at $-80^{\circ} \mathrm{C}$ until work-up. At the admission and the release of the patients blood samples were also sent to the national reference laboratory for serological investigation. Omniscript reverse transcription kit (Qiagen ${ }^{\circledast}$, Germany) was used for the cDNA synthesis in accordance with the instructions of the manufacturer.

Primers from S segment of the virus were selected for the first and second round amplifications. For this purpose, $\mathrm{S}$ segment sequences from different geographic regions. (GeneBank accession numbers and origines of the strains:

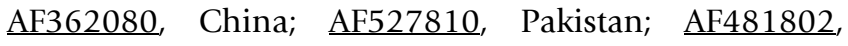
Uzbekistan; AJ010648, China; AJ538198, Pakistan; AJ538196, Iraq; AY277672, Russia; AY277676, Bulgaria; AY508484, Turkey; AY366385, Iran; DQ076416, South Africa; DQ076415, Uganda; DQ227496, China; DQ217602, China; DQ227495, China; DQ214644, Russia; DQ133507 Kosovo; DQ211649, Turkey; U88412, Russia; U04958, Greece; U88410, Africa; U88415, Africa) were downloaded from the GeneBank and aligned using Clustal Wallis [9] software program. The sites of the possible primers were selected visually and evaluated using Primer test option of Primer Express software (Applied Biosystems ${ }^{\circledast}$, USA).

Five forward and 2 reverse primers were designed initially. Based on the results of the optimization and assesment of the performance of the primers performed using CCHF virus CDNA and PCR optimization kit (Sigma ${ }^{\circledR}$, Germany) with different $\mathrm{Mg}^{++}$and primer concentrations, two forward and one reverse primer were selected for routine use. All but one of the remaining primers were used as sequencing primers. The sequences of the primers numbered based on the sequence of Hodza strain (AY223475) (Table 1).

Five $\mu$ reverse transcription product was added to the 45 $\mu \mathrm{l}$ reaction mixture consisted of $1 \mu \mathrm{l}$ forward primer (50 $\mathrm{pmol} / \mu \mathrm{l})$ ) and $1 \mu \mathrm{l}$ reverse primer $(50 \mathrm{pmol} / \mu \mathrm{l}), 5 \mu \mathrm{l} 10 \times$ reaction buffer, $3 \mu \mathrm{l} 25 \mathrm{mM} \mathrm{MgCl}_{2}, 1 \mu \mathrm{l}$ dNTP stock (200 $\mathrm{mM}$ each dATP, dTTP, dCTP and dGTP) (Fermentas ${ }^{\varpi}$, Lithuania), $0.25 \mu \mathrm{l}$ Taq DNA polymerase (Fermentas ${ }^{\circledR}$, Lithuania) and $33.75 \mu \mathrm{l}$ nuclease free water. Amplification was carried out on a gradient thermal cycler under following conditions: After initial denaturation for $3 \mathrm{~min}$ utes at $94^{\circ} \mathrm{C} ; 45$ cycles of 1 minute at $94^{\circ} \mathrm{C}, 1$ minute at $52^{\circ} \mathrm{C}$ and 3 minutes at $72^{\circ} \mathrm{C}$. Final extention was performed at $72{ }^{\circ} \mathrm{C}$ for 10 minutes. For the second round amplification $2 \mu \mathrm{l}$ first round products was added to the $48 \mu$ reaction mixture with the same concentrations of 
Table I: The primers and nucleotide numbers according to the Hodhza strain

\begin{tabular}{lccr}
\hline CCF-5F & & aaa cac gtg ccg ctt acg cc & $(5-24)$ (this study) \\
\hline CCF-II5F & First round & aar gga aat gga ctt rtg ga & $(115-134)($ this study) \\
CCF-13IF & Second round & tgg aya cyt tca caa act cc & $(131-152) *$ \\
CCF-295F & Sequencing & tgg gty agc tcy acy ggy att gt & $(295-312)($ this study) \\
CCF-457F & Sequencing & gac ata ggt tty cgt gty aat gc & $(457-479)($ this study) \\
CCF-479R & Sequencing & gca ttr aca cgr aar cct tat gtc & $(479-457)($ this study) \\
\hline CCF-759R & First and second round & gca agg cct gtw gcr aca agt gc & $(759-736)($ this study) \\
\hline
\end{tabular}

* Modified from reference [23]

the first round mixture. Also the thermal cycling conditions were same. The amplification products were visualized on $1.5 \%$ agarose gel electrophoresis under UV-light.

The second round PCR products were cleaned up with a commercial PCR product purification kit (High Pure PCR Product Purification Kit, Roche Diagnostics ${ }^{\oplus}$, Germany and the purified products were subjected to the cyclesequencing using big-dye terminator kit ( $\left.\mathrm{ABI}^{\circledR}, \mathrm{USA}\right)$. The excess primers and nucleotides were removed from cyclesequencing products using sephadex-G50 fine columns, and the products were run on an automated sequencer $\left(\mathrm{ABI} \mathrm{I}^{\oplus}, 310\right)$.
The obtained sequences were edited and aligned using lasergene (DNA Star ${ }^{\circledast}$ ) and Bioedit software packages [10]. The sequences belonging to five patients were deposited to the GeneBank under the accession numbers: DQ983741， DQ983742， DQ983743， DQ983744， DQ983745. For molecular analyses and comparisons, a portion spanning 593 (between 146-739. nucleotides; numbering according to Hodza strain, AY223475) nucleotides of the S segment was used. Phylogenetic analyses were carried out by distance method using neighbor joining algorithm with Treecon, version 1.3b software [11]. Distances were calculated under Kimura 2 parameter model. Transition/transversion ratio was estimated from the data. Neither insertions nor deletions were taken in to

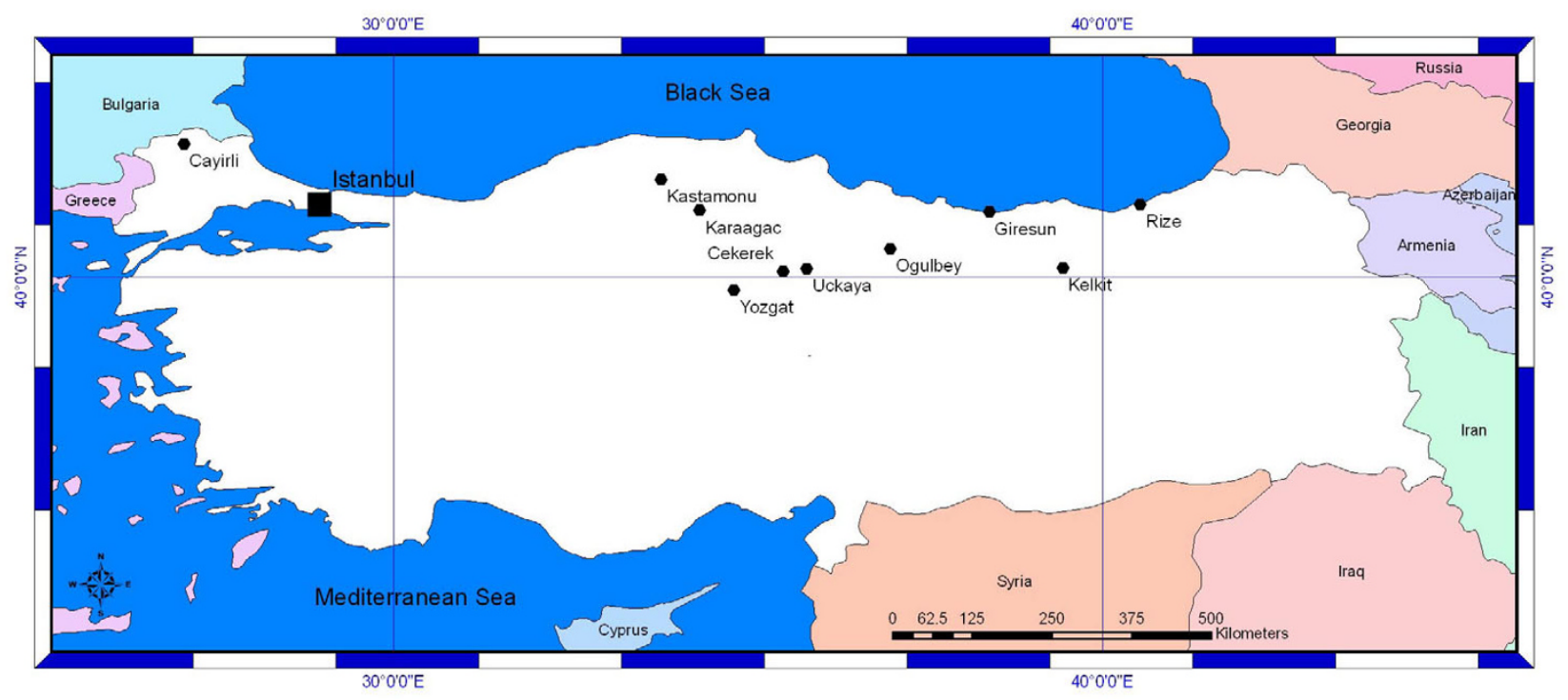

Figure 2

The Geographic Origin of the Imported Cases. 
Table 2: Demographic characteristics of the patients

\begin{tabular}{|c|c|}
\hline & 10 patients $(\%)$ \\
\hline Number of females & $6(60)$ \\
\hline Mean age (range) & $40(13-67)$ \\
\hline History of tick bite & $6(60)$ \\
\hline $\begin{array}{l}\text { Days from symptoms to admission (median, min- } \\
\text { max) }\end{array}$ & $6.5(3-7)$ \\
\hline Length of stay in the hospital & $10(4-13)$ \\
\hline \multicolumn{2}{|l|}{ Symptoms and signs } \\
\hline Fever & $10(100)$ \\
\hline Petechia & $8(80)$ \\
\hline Maculopapular rash & $6(60)$ \\
\hline Myalgia & $8(80)$ \\
\hline Headache & $8(80)$ \\
\hline Gingival bleeding & $4(40)$ \\
\hline Vaginal bleeding & $\mathrm{I}(10)$ \\
\hline Epistaxis & $5(5)$ \\
\hline Hematuria & $\mathrm{I}(10)$ \\
\hline Somnolence & 0 \\
\hline
\end{tabular}

account. Topologic accuracy of the tree was evaluated by bootstrap method (1000 replicates) and only bootstrap values $\geq 65 \%$ were considered significant.

The informed consents from the patients were obtained. This was an observational study, which was conducted in compliance with Helsinki declaration.

\section{Results}

\section{The characteristics of the cases}

Between 12 June 2006 and the end of the October 2006, 91 CCHF suspected cases applied to the hospitals in the urban area of Istanbul (Figure 1). Among these, PCR bands corresponding to the expected size $(628 \mathrm{bp})$ product of the $S$ segment were detected in 10 patients. All PCR positive patients except one were also confirmed by IgM seropositivity. All of the PCR negative patients were also serologically negative. These patients were from Çorum

Table 3: Pathologic laboratory findings of the patients

\begin{tabular}{ll}
\hline & $\begin{array}{l}10 \text { patients (\%) Median } \\
\text { (min-max) }\end{array}$ \\
\hline $\begin{array}{l}\text { Longest Prothrombin time, s } \\
\text { Longest activated partial thromboplastin }\end{array}$ & $11.6(9.8-15.2)$ \\
time, $s$ & $31.9(26.6-40)$ \\
Lowest platelet count, platelets $/ \mathrm{mm}^{3}$ & $50,000(20,000-140,000)$ \\
Lowest WBC, WBCs/mm & $2900(1800-3500)$ \\
Highest alanine transferase level, U/L & $151(53-319)$ \\
Highest aspartate transferase level, U/L & $308(47-581)$ \\
Highest lactic dehydrogenase level, U/L & $940(494-1657)$ \\
\hline
\end{tabular}

Highest creatinine phosphokinase level, 266 (250-583) $U / L$

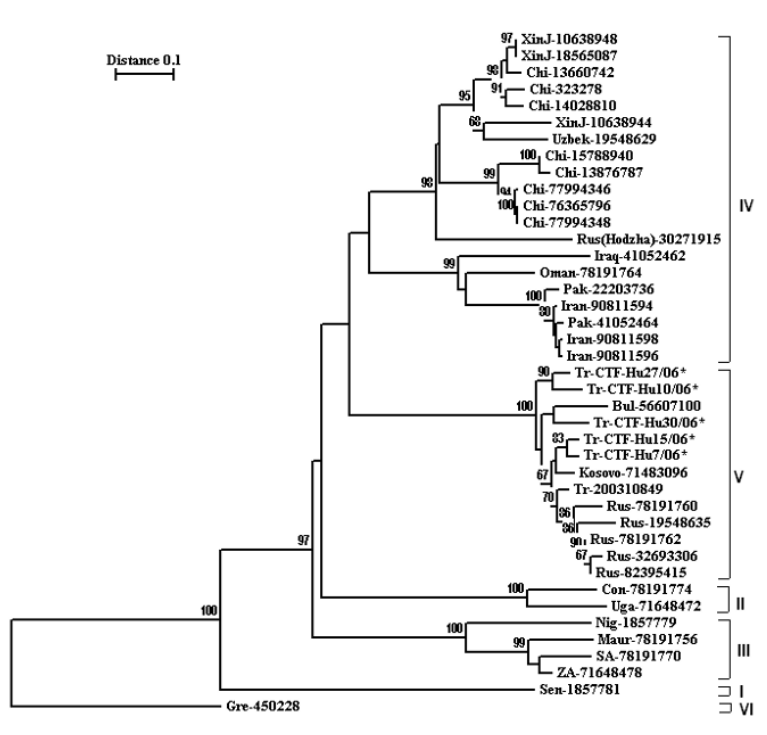

\section{Figure 3}

Phylogenetic tree for the CCHF strains. *: New Turkish strains detected by this study. I: West Africa. II: Democratic Republic of Congo. III: South/West Africa. IV: Asia/Middle East. V:Europe/Turkey. VI: Greece

(1), Giresun (1), Gümüşhane (1), Kastamonu (1), Kýrklareli (1), Rize (1), Tokat (2) and Yozgat (2) (Figure $2)$. Demographic, clinical and laboratory characteristics of the patients were depicted in Table 2 and Table 3.

\section{Sequence analyses}

Although the patients came from different localities of Turkey or had indirect contact with different endemic areas, the sequences of CCHFv were closely related. The nucleotide variation ranged between $0.66 \%$ and $3 \%$, and this variation did not result in any amino acid substitution. In comparisons with the representative strains from different geographic regions, the strains detected in Istanbul showed highest homologies with Eastern European strains. Nucleotide and amino acid diversities varied between $1.16 \%-3.17 \%$ and $0-1$ respectively (DQ1335071， DQ211643). Higher nucleotide and amino acid divergencies $(21.20 \%$ and $20 \%$ respectively) were observed in comparisons with representative strains from Asian (AJ538196, M86625, DQ446212), and African (U88411, U88410, DQ076413) clades, and the Greek isolate (U04958). A total of 41 sequences of CCHFv S segment were used for the construction of the phylogenetic tree. In this tree the strains clustered with high bootstrap values reaching up to $100 \%$ in 6 clusters reflecting their different origins as shown previously. Our strains clustered in the Europe/Turkey clade [12] (Figure 3). 


\section{Discussion}

Since CCHF was endemic for the last four years in Eastern Anatolia, the ad hoc committee for CCHF in Istanbul initiated series of activities including the management of the suspected cases, in a city with the population of over 10 millions. A public awareness campaign was launched which included brochures, TV programs, and public health worker education programs about early diagnosis and preventive measures concerning tick bites and CCHF infections. As a result, there is improved surveillance and diagnosis of suspected cases (Figure 1). It is possible that previous introductions have gone unnoticed, especially since the majority of the cases appear to be relatively mild.

Suspected CCHF infections in people traveling from endemic regions to disease-free areas, such as Istanbul, were confirmed in 10 out of 91 cases. Nine out of 10 cases were from Eastern Anatolian provinces, where cases were reported previously $[2,3,13]$. However, one case originated from Kirklareli near the border with Bulgaria, which is the first report from this area (Figure 2). Imported cases of CCHF were reported previously, as cases from people traveling from one country to another $[14,15]$.

Sixty percent of our patients reported the tick bite, and all the patiens had been bitten out of Istanbul (Table 2). The HCWs facing with the suspected cases should be aware that, a significant proportion of the suspected cases did not report tick bite, as it was previously published [1]. In South Africa, the time to onset of disease after exposure to tick bite was 3.2 days, to blood or tissue of livestock was 5 days, and to blood of human cases was 5.6 days [16]. The mean duration of the disease course before the hospital was reported to be 5.5 days in a previous study from Turkey [2]. However in our study, the average time from onset of disease to admission to hospital was 7 days (Table 2). None of the cases was fatal. The patients were given erythrocyte, fresh frozen plasma, and total blood preparations depending on their hemostasis. All the patients were given ribavirin therapy before the virologic evidence of CCHF infection.

Although the genetic heterogeneity of tick-borne RNA viruses is generally low, CCHFv shows a high level of genetic heterogeneity up to $22 \%$ nucleotide variations and $27 \%$ amino acid variations based on the S fragment, which is reflected into six genetically distinct clades [12]. Although confirmed patients came from 8 different localities in Turkey, all CCHFv sequences were closely related. The nucleotide variation ranged between $0.66 \%$ and $3 \%$, and this variation did not result in any amino acid substitution. In comparison with representative strains from different geographic regions, those strains found in this study displayed the highest homology with the Eastern European and some Russian isolates (clade V)(Fig. 3).
Also, CCHF is endemic in neighboring countries and genetically distant strains circulate in Bulgaria, Iran and Greece [17-19]. Moreover, in Iran, two different lineages of the virus have been reported; one belonging to the Asian-Middle Eastern clade and the other to the African clades [18]. Strains reported from Iraq and Arabian countries were closely related to those reported from Iran. Nevertheless, strains from the Eastern European countries and South-western Russia form a distinct group with relatively low heterogeneity (Figure 3 ).

Although relatively few sequences are available since the disease outbreaks were recorded in Turkey for the first time in 2003, those which are available are related to viral lineages found in Kosovo and South-western Russia [3]. Furthermore, viral strains in ticks collected from the endemic region where the first outbreaks occurred, were also found to be closely related with the Europe/Turkey strains $[20,21]$. In our study, all strains clustered within the same group with the Europe/Turkey isolates, despite they originated from eight different geographic areas, 7 previously known and one focus on the European part of the Turkey, which was identified in this study (Figure 3). Interestingly one strain (SPU 9/00/5) from Iran reported by Burt and Swaenopel [22] clustered also with Europe/ Turkey clade.

Despite more viral strains are needed to draw any definite conclusion, it appears the emergence of CCHF in Turkey may be the result of an amplification of local viral isolates by wildlife populations rather than resulting from novel introductions from neighbouring countries. Continued surveillance to monitor suspected CCHF cases, not only within known foci, but also outside endemic areas as reported herein, is required.

\section{Competing interests}

The author(s) declare that they have no competing interests.

\section{Authors' contributions}

All authors read and approved the final manuscript

1. Kenan Midilli: study design, microbiological laboratory studies, analysis of the results and manuscript preparation

2. Ayşen Gargıll: study design, microbiological laboratory studies, analysis of the results and manuscript preparation

3. Onder Ergonul: study design, analysis of the results and manuscript preparation

4. Gönül Şengöz: study design, organization of the data collection, analysis of the results 
5. Recep Ozturk: study design, analysis of the results

6. Mehmet Bakar: study design, organization of the data collection, analysis of the results

\section{Frans Jongejan: manuscript preparation}

\section{Acknowledgements}

We would like to thank Dr. Ramazan Uzun, DVM from MOH of Turkey, for his kind collaboration and comments. We thank to Dr. Zati Vatansever, DVM for constructing the map of the distribution of the cases, and Dr. Agustin Estrada Pena, DVM for his critical review and the comments.

\section{References}

I. Ergonul O: Crimean-Congo haemorrhagic fever. Lancet Infect Dis 2006, 6(4):203-2। 4 .

2. Ergonul O, Celikbas A, Dokuzoguz B, Eren S, Baykam N, Esener H: Characteristics of patients with Crimean-Congo hemorrhagic fever in a recent outbreak in Turkey and impact of oral ribavirin therapy. Clin Infect Dis 2004, 39(2):284-287.

3. Karti SS, Odabasi Z, Korten V, Yilmaz M, Sonmez M, Caylan R, Akdogan E, Eren N, Koksal I, Ovali E, et al.: Crimean-Congo hemorrhagic fever in Turkey. Emerg Infect Dis 2004, I 0(8): 1379- 384.

4. Bakir M, Ugurlu M, Dokuzoguz B, Bodur H, Tasyaran MA, Vahaboglu $\mathrm{H}$ : Crimean-Congo haemorrhagic fever outbreak in Middle Anatolia: a multicentre study of clinical features and outcome measures. J Med Microbiol 2005, 54(4):385-389.

5. The reports of Communicable Diseases Department, Ankara. 2006.

6. Whitehouse CA: Crimean-Congo hemorrhagic fever. Antiviral Res 2004, 64(3): I45-160.

7. Casals J: Antigenic similarity between the virus causing Crimean hemorrhagic fever and Congo virus. Proc Soc Exp Biol Med 1969, I 3 I(I):233-236.

8. Donets MA, Rezapkin GV, Ivanov AP, Tkachenko EA: Immunosorbent assays for diagnosis of Crimean-Congo hemorrhagic fever (CCHF). Am J Trop Med Hyg 1982, 3 I(I): I56-I62.

9. Thompson JD, Higgins DG, Gibson TJ: CLUSTAL W:improving the sensitivity of progressive multiple sequence alignment through sequence weighting, position-specific gap penalties and weight matrix choice. Nucleic Acids Res 1994, 22(22):4673-4680.

10. Hall TA: BioEdit: a user-friendly biological sequence alignment editor and analysis program for Windows 95/98/NT. Nucl Acids Symp 1999:95-98.

II. Van de Peer Y, De Wachter R: Construction of evolutionary distance trees with TREECON for Windows: accounting for variation in nucleotide substitution rate among sites. Comput Applic Biosci 1997, 13:227-230.

12. Deyde VM, Khristova ML, Rollin PE, Ksiazek TG, Nichol ST: Crimean-Congo hemorrhagic fever virus genomics and global diversity. J Virol 2006, 80( I 7):8834-8842.

13. Ergonul O, Celikbas A, Baykam N, Eren S, Dokuzoguz B: Analysis of risk-factors among patients with Crimean-Congo haemorrhagic fever virus infection: severity criteria revisited. Clin Microbiol Infect 2006, I 2(6):55I-554.

14. Tarantola A, Nabeth P, Tattevin P, Michelet C, Zeller H: Lookback exercise with imported Crimean-Congo hemorrhagic fever, Senegal and France. Emerg Infect Dis 2006, I2(9): I424- I 426.

15. Jaureguiberry S, Tattevin P, Tarantola A, Legay F, Tall A, Nabeth $P$, Zeller H, Michelet C: Imported Crimean-Congo hemorrhagic Fever. J Clin Microbiol 2005, 43(9):4905-4907.

16. Swanepoel R, Shepherd AJ, Leman PA, Shepherd SP, McGillivray GM, Erasmus MJ, Searle LA, Gill DE: Epidemiologic and clinical features of Crimean-Congo hemorrhagic fever in southern Africa. Am J Trop Med Hyg 1987, 36(I): I20-132.

17. Papa A, Christova I, Papadimitriou E, Antoniadis A: Crimean-Congo hemorrhagic fever in Bulgaria. Emerg Infect Dis 2004, I0(8): | $465-\mid 467$.

18. Chinikar S, Persson SM, Johansson M, Bladh L, Goya M, Houshmand B, Mirazimi A, Plyusnin A, Lundkvist A, Nilsson M: Genetic analysis of Crimean-congo hemorrhagic fever virus in Iran. J Med Virol 2004, 73(3):404-4II.

19. Antoniadis A, Casals J: Serological evidence of human infection with Congo-Crimean hemorrhagic fever virus in Greece. Am J Trop Med Hyg 1982, 3 I(5): 1066-1067.

20. Tonbak S, Aktas M, Altay K, Azkur AK, Kalkan A, Bolat Y, Dumanli N, Ozdarendeli A: Crimean-Congo hemorrhagic fever virus: genetic analysis and tick survey in Turkey. J Clin Microbiol 2006, 44(II):4I20-4I24.

2I. Whitehouse CA, Hottel H, Deniz A, Vatansever Z, Ergonul O, Paragas J, Garrison A, Kondig JP, Wasieloski LP: Molecular Detection of Crimean Congo Hemorrhagic Fever Virus in Ticks from Turkey. American Society of Tropical Medicine and Hygiene, 55th Annual Meeting November 12-16, 2006; Atlanta, GA USA . November 12-16, 2006.

22. Burt FJ, Swanepoel R: Molecular epidemiology of African and Asian Crimean-Congo haemorrhagic fever isolates. Epidemiol Infect 2005, I 33(4):659-666.

23. Rodriguez LL, Maupin GO, Ksiazek TG, Rollin PE, Khan AS, Schwarz TF, Lofts RS, Smith JF, Noor AM, Peters CJ, et al.: Molecular investigation of a multisource outbreak of Crimean-Congo hemorrhagic fever in the United Arab Emirates. Am J Trop Med Hyg 1997, 57(5):5|2-5|8.

\section{Pre-publication history}

The pre-publication history for this paper can be accessed here:

http://www.biomedcentral.com/1471-2334/7/54/prepub
Publish with Biomed Central and every scientist can read your work free of charge

"BioMed Central will be the most significant development for disseminating the results of biomedical research in our lifetime. "

Sir Paul Nurse, Cancer Research UK

Your research papers will be:

- available free of charge to the entire biomedical community

- peer reviewed and published immediately upon acceptance

- cited in PubMed and archived on PubMed Central

- yours - you keep the copyright

Submit your manuscript here:

http://www.biomedcentral.com/info/publishing_adv.asp
BioMedcentral 